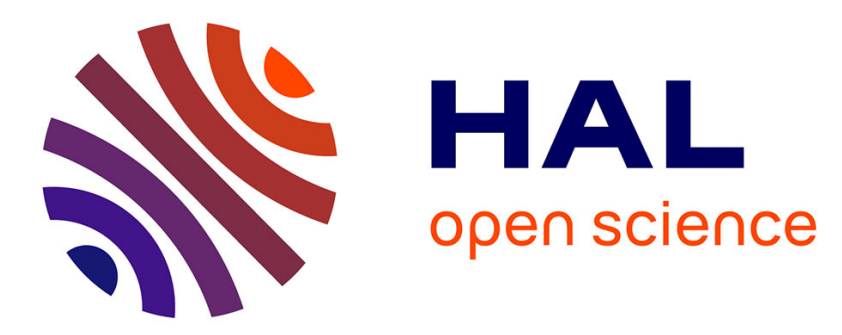

\title{
Cytotoxic effect of different statins and thiazolidinediones on malignant glioma cells
}

Jorge Humberto Tapia-Pérez, Elmar Kirches, Christian Mawrin, Raimund Firsching, Thomas Schneider

\section{- To cite this version:}

Jorge Humberto Tapia-Pérez, Elmar Kirches, Christian Mawrin, Raimund Firsching, Thomas Schneider. Cytotoxic effect of different statins and thiazolidinediones on malignant glioma cells. Cancer Chemotherapy and Pharmacology, 2010, 67 (5), pp.1193-1201. 10.1007/s00280-010-1535-2 . hal00646936

\section{HAL Id: hal-00646936 \\ https://hal.science/hal-00646936}

Submitted on 1 Dec 2011

HAL is a multi-disciplinary open access archive for the deposit and dissemination of scientific research documents, whether they are published or not. The documents may come from teaching and research institutions in France or abroad, or from public or private research centers.
L'archive ouverte pluridisciplinaire HAL, est destinée au dépôt et à la diffusion de documents scientifiques de niveau recherche, publiés ou non, émanant des établissements d'enseignement et de recherche français ou étrangers, des laboratoires publics ou privés. 


\title{
Cytotoxic effect of different statins and thiazolidinediones on malignant glioma cells
}

\author{
Jorge Humberto Tapia-Pérez ${ }^{1,2}$, Elmar Kirches ${ }^{2}$, Christian Mawrin ${ }^{2}$, \\ Raimund Firsching ${ }^{1}$, Thomas Schneider ${ }^{1}$
}

1. Department of Neurosurgery, Otto von Guericke University Magdeburg.

2. Department of Neuropathology, Otto von Guericke University Magdeburg.

Correspondence:

Tapia-Pérez, J. Humberto

Klinik für Neurochirurgie

Otto-von-Guericke Universität, Magdeburg

Leipziger Strasse 44

39120 Magdeburg

Tel... +49 (0) 391/ 6715534

Fax: +49 (0) 391/6715544

jorge.tapia@med.ovgu.de 


\section{Abstract \\ Purpose}

Glioblastoma multiforme is still a tumor with very poor prognosis. Statins are actually used for treatment of dyslipidemias and thiazolidinediones for improving insulin sensitivity in diabetes. Statins are inhibitors of the cholesterol pathway, while thiazolidinediones are peroxisomal proliferator activator receptor $Y$ (PPAR) agonists. For both a potent pro-apoptotic activity has been suggested.

\section{Methods}

We compared the anti-glioma effect of simvastatin, atorvastatin, lovastatin, pravastatin, rosuvastatin, rosiglitazone, pioglitazone and their combinations at several concentrations on human glioblastoma cell lines U87, U 138, LN 405 and rat RG II. The cytotoxic effect was assessed using a cell proliferation assay after 48 and 144 hours. Caspase 3 activity and the addition of isoprenoids and PPAR-y inhibitor GW9662 were assessed. Experiments were as well conducted under hypoxia for 24 hours.

\section{Results}

We demonstrated a significant cytotoxic effect with a combination of statins plus pioglitazone. The effect was observed after $48 \mathrm{~h}$ and dramatically increased after $144 \mathrm{~h}$. The combination of 2 types of statins (synthetic and natural) allowed a 5-fold dose reduction. Statin effect was reversed with isoprenoids and partially with PPAR-Y antagonists, while thiazolidinediones effect was slightly affected by PPAR- $Y$ antagonists. A marked increase of caspase 3 activity was achieved by combining atorvastatin with lovastatin. Cytotoxicity of the combination of statins and thiazolidinediones did not decrease under hypoxia.

\section{Conclusion}

The assessed combination of statins with thiazolidinediones shows a synergistic cytotoxic effect against glioblastoma cells in vitro, which could represent a feasible therapeutic schema.

Keywords: cytotoxicity; glioblastoma; statin; thiazolidinediones 


\section{Introduction}

Glioblastoma multiforme is the most common malignant brain tumour with a very poor prognosis. Despite the best current therapy the median overall survival and progression-free intervals are short $[23,31,32,37]$. New therapeutic approaches are urgently needed.

Statins are structural substrate-analogues of $\beta$ hydroxy- $\beta$-methylglutaryl coenzyme A (HMG CoA) reductase, a rate-limiting enzyme of the cholesterol pathway. Statins reduce serum cholesterol levels as well as the mevalonate synthesis, which is a requisite for entry of normal and tumor cells into the cell cycle. The production of mevalonate derivates is reduced and accordingly the levels of dolichol, ubiquinone, geranyl geranyl-pyrophosphate (GGPP), and farnesyl-pyrophosphate (FPP). These metabolites are required for posttranslational isoprenylation of GTP-binding proteins such as Ras and Rho, which regulate cell proliferation [20]. Ras and Rho are thought to play an essential role in activation of phosphorylation cascades such as the MAPKs (Mitogen-Activated Protein Kinase) pathway [20]. Statins are currently used for treatment of dyslipidemias and prevention of cardiovascular diseases, so far as reduction of stroke incidence $[2,12]$. In addition to their primary use, the anticancer activity of statins was intensively studied for several kinds of tumours. The overall response rates in these studies however were limited [17]. Thiazolidinediones (TDZ) are agonists of peroxisome proliferator-activated receptor $Y$ (PPAR). Besides its primary use in improving insulin sensitivity in type 2 diabetes mellitus, an anticancer activity was found $[9,16,27,34]$.

Recent studies on malignant glioma are restricted to simvastatin and lovastatin, so as to cerivastatin, which is no longer available on the market $[4,6,7,13,15,20,21,24,33,36,38,41,42,43]$. A comparison of statins has not been reported yet. For thiazolidinediones, some studies have compared the 4 available TDZ with variable results $[8,36]$. Agents that may synergize with statins or thiazolidinediones may substantially improve their application in clinical oncology. An increased effect could be demonstrated when combining both medicaments with other anticancer agents [3, 6, 39, 42-44]. Particularly, a combination of both drugs might be reasonable, because both drugs are able to modulate the lipid metabolism. Recently it has been suggested, that an activation of PPARs receptor by statins could be 
increased by TDZ [48]. The combination of lovastatin and troglitazone has already been proposed for increased antitumor activity [49].

Important differences among pleiotropic effects of different statins have been suggested $[29,40,50]$. For the most effective therapeutic regimen of statins and thiazolidinediones, it would be necessary to establish the most effective drug of each family. Other important considerations should be the clinically achievable concentration in plasma respectively in tumor cells as well as moderate and tolerable side effects. We hypothesized the existence of an important difference in the effects of statins alone as compared with their combinations with thiazolidinediones, which would allow developing an effective chemotherapeutic regimen.

Recently, studies by Akasaki et al. and Cafforio et al. indicate a facilitation of caspase 8 and 9, important activators of caspase 3 in the apoptosis pathway, by TDZ on glioma cells and by statins on myeloma cells $[3,5]$. The direct or indirect effect of a combined therapy on caspase 3 activity has not been analyzed as of yet.

Hypoxia, typically found in tumoral environment, has become an important factor in chemo- and radioresistance [19]. An optimal therapy should be minimally affected by hypoxia or even better, it should be enhanced. We also studied the effect of a combination of TDZ and statins under hypoxic conditions for testing the performance in this principally different setting.

\section{Material and methods}

\section{Cell cultures}

Three human malignant glioma cell lines (U87, U138, and LN405) and a rat glioma cell line (RG II) were investigated. The cell lines U87, U138, RG II were supplied by American Type Culture Collection (Manassas, VA, USA), the cell line LN405 from the German Collection of Microorganisms and cell cultures (Braunschweig, Dtd). The cell medium for cell lines U87 and U138 was minimum essential medium Eagle with Earl's salts and L-Glutamin and for cell lines LN405 and RG II was RPMI 1640 with L-Glutamin. All media were supplemented with $10 \%$ fetal calf serum and the cells were grown at $37^{\circ} \mathrm{C}$. The cells were seeded at a density of 2,000 cells per well into 96-well microtiter plates. After a 24-h 
preincubation in a volume of $100 \mu \mathrm{L}$ of the appropriate cell culture medium the cells were treated with study relevant drugs for $48 \mathrm{~h}$ or $144 \mathrm{~h}$ followed by MTT-assay. The experiments were accomplished under normoxia $(21 \% \mathrm{O} 2)$.

Additional experiments were performed in conditions of hypoxia $(0.1 \% \mathrm{O} 2)$ for $24 \mathrm{~h}$. For hypoxic treatment, cells were placed in Modular Incubator Chambers, which were flushed with $94 \% \mathrm{~N} 2,5 \% \mathrm{CO} 2$ sealed, and then kept in a regular tissue culture incubator. After incubation, plates were collected and analyzed for surviving cells by MTT-assay.

\section{Drugs}

Stock solutions of atorvastatin (synthetic statin), and the natural statins lovastatin, pravastatin, simvastatin were prepared from commercially available tablets using standard techniques [50]. The same procedure was applied for pioglitazone and rosiglitazone. Rosuvastatin calcium salt (synthetic statin) was synthesized at AstraZeneca Pharmaceuticals (United Kingdom). Geranygeranyl Pyrophosphate, Farnesyl Pyrophosphate and GW 9662 were obtained from Sigma (St. Louis, MO). Drug stocks were prepared at 1000-fold greater than experimental concentrations.

\section{Cell viability assay}

Cell viability was determined by the colorimetric 3-(4,5-dimethyl-2-thiazolyl)-2,5-diphenyl-2H tetrazolium bromide assay (Sigma-Aldrich, Germany). After the different times corresponding to the treatment schedule the cells were incubated for another $2 \mathrm{~h}$ at $37^{\circ} \mathrm{C}$ with the tetrazolium salt to allow formazan formation. Then lysates were prepared by 15 min shaking at room temperature with DMSO, which also serves as a solvent for the formazan dye. The absorbance at $562 \mathrm{~nm}$ (reference wavelength 620 $\mathrm{nm}$ ) was determined in an ELISA reader (Anthos, Krefeld, Germany). Viable cells were expressed as percentage of absorbance with respect to control/vehicle cells which was considered as $100 \%$.

\section{Prenoids and PPAR antagonist}

In order to assess the possible mechanism by which statins induce cytotoxicity, we applied the prenoids geranygeranyl pyrophosphate and farnesyl pyrophosphate at $10 \mu \mathrm{M}$. We hypothesized that statins could also activate PPAR- $\gamma$. We tested the effects after application of the PPAR-y antagonist GW9662 at $20 \mu \mathrm{M}$. For that assessment we repeated the above mentioned experiments with statin, TDZ and their 
combinations while adding prenoids and the antagonist GW9662. All the substances were applied simultaneously with the tested drug treatment on U87cells. After 48 hours the cell viability assay was accomplished and compared with controls.

\section{Caspase- 3 function assay}

Caspase activation of treated U87 cells was determined following the instructions of a caspase-3 detection kit (Bio Vision). Cells were lysed in a lysis buffer, and whole-cell lysates $(20 \mu \mathrm{g})$ were incubated with 25 $\mu \mathrm{mol} / \mathrm{L}$ fluorogenic substrate DEVD-AFC in a reaction buffer (containing $5 \mathrm{mmol} / \mathrm{L}$ DTT) at $37^{\circ} \mathrm{C}$ for 2 h. Proteolytic release of AFC was monitored at $\mathrm{ex}=405 \mathrm{~nm}$ and $\mathrm{em}=500 \mathrm{~nm}$ using a microplate reader (Tecan, Crailsheim). Fold increase of the fluorescence signal was calculated for each treated sample by dividing its normalized signal activity by that of the untreated control.

\section{Statistical analysis}

We used SPSS v.14 for Windows and R 2.5.2. All data were expressed as mean \pm SD. Cellular viability and caspase activity data were analyzed by one-way ANOVA followed by multiple comparisons using Least Significant Difference (LSD). For drug application under hypoxia we fitted linear regression models. Statistical significance was $p<0.05$.

\section{Results}

\section{Comparison of cytotoxic effects of statins and TDZ}

We tested the different drugs as single treatment on different cell lines. After 48 hours the maximal effect of statins was determined for lovastatin or simvastatin on cell lines U87, RGII, U138, and LN 405 with around $60 \%$ surviving cells. The subsequent order of cytotoxicity was identified: lovastatin = simvastatin $>$ atorvastatin $>$ pravastatin $>$ rosuvastatin (Fig. 1). The incubation with statins for 144 hours increased the toxicity with minimal surviving cells of $15 \%$ (for $5 \mu \mathrm{M}$ lovastatin on $\mathrm{U} 87$ cell line) and of $27 \%$ (for $2.5 \mu \mathrm{M}$ simvastatin on U87 cell line) (Fig. 1).

After 48 hours pioglitazone $40 \mu \mathrm{M}$ was able to reduce the cell survival to $45 \%$ (U138), respectively $81 \%$ (U87). A mean cell survival of about $80 \%$ was observed with 2.5-5 $\mu \mathrm{M}$ pioglitazone (Figure 1). Rosiglitazone showed lower effect with a mean survival of $85 \%$ in all the assessed cell lines and with 
concentrations between $0.5 \mu \mathrm{M}$ and $25 \mu \mathrm{M}$. After 144 hours the effect was significantly increased with a minimal rate of surviving cells of $35 \%$ on RG II after $25 \mu \mathrm{M}$ pioglitazone and $59 \%$ on U87 after $25 \mu \mathrm{M}$ piogliotazone, respectively (Fig 1).

\section{Combination of statin and TDZ}

To improve the cytotoxic effect and to reduce the required dose, we combined one statin and one TDZ. The combinations with pioglitazone were more effective than with rosiglitazone. In comparison with a single drug, a lower dose was required. After 48 hours (cell line U87) the most effective combination was lovastatin $5 \mu \mathrm{M}+$ pioglitazone $40 \mu \mathrm{M}(47 \%$ surviving cells), followed by atorvastatin $1.5 \mu \mathrm{M}+$ pioglitazone $40 \mu \mathrm{M}(52 \%$ surviving cells), simvastatin $2.5 \mu \mathrm{M}+$ pioglitazone $40 \mu \mathrm{M}$ (52\% surviving cells) and pravastatin $4 \mu \mathrm{M}+$ pioglitazone $40 \mu \mathrm{M}$ (69\% surviving cells).

After 144 hours the lowest surviving cell fraction of cell line U87 was $6 \%$ with atorvastatin $1.5 \mu \mathrm{M}+$ pioglitazone $40 \mu \mathrm{M}$. A similar cytotoxic effect occurred with combinations of pioglitazone and lovastatin or simvastatin, but not for TDZ with pravastatin $(40 \%)$ or rosuvastatin $(15 \%)$. Clinically pioglitazone 40 $\mu \mathrm{M}$ carries a high risk for unwanted side effects. Pioglitazone $5 \mu \mathrm{M}$ after 48 hours showed a modest effect. Its combination with atorvastatin $1.5 \mu \mathrm{M}$ (around $60 \%$ cell survival after 48 hours) was discreet less effective than with $40 \mu \mathrm{M}(52 \%)$ (Figure 2B).

\section{Potentiating of statin by statin}

The statins can induce different pleiotropic effects, which are variable for each substance. Natural and synthetic statins are basically different from each other. With this premise we investigated combinations of these. The combination of lovastatin $5 \mu \mathrm{M}+$ atorvastatin $1.5 \mu \mathrm{M}$ substantially increased the cytotoxicity after 48 hours of incubation (43\% surviving cells, cell line U87) as well as the combination of lovastatin 5 $\mu \mathrm{M}+$ rosuvastatin $1.5 \mu \mathrm{M}$ (32\% surviving cells). At a lower dose a toxicity of $50 \%$ was noted. The combination of rosuvastatin $1.5 \mu \mathrm{M}$ + atorvastatin $1.5 \mu \mathrm{M}$ (both synthetic) did not lead to more efficiency. All combinations with simvastatin exhibited a lower toxicity than those with lovastatin.

In pharmacological and animal studies it is shown that a high concentration of a statin is not easily achievable in tumours [21]. Additionally, the risk of unwanted side effects increases with dose. For that reason we tested combinations of lovastatin and atorvastatin a lower dose of one and an increasing of the 
other one. In this way, similar effects like maximal dose (atorvastatin $1.5 \mu \mathrm{M}+$ lovastatin $5 \mu \mathrm{M}, 43 \%$ cell survival) were achieved with atorvastatin at $1.5 \mu \mathrm{M}+$ lovastatin $0.5 \mu \mathrm{M}$ or $1 \mu \mathrm{M}(50 \%$ and $42 \%$ surviving cells, respectively).

\section{Combination of three substances}

Statins and PGZ showed a synergic effect as well as a combination of synthetic and natural statins. By combining three drugs, it was possible to achieve a slightly better effect with an important dose-reduction. The combination of lovastatin $5 \mu \mathrm{M}+$ atorvastatin $1.5 \mu \mathrm{M}+$ pioglitazone $40 \mu \mathrm{M}$ reduced surviving cells to $29.6 \%$ after 48 hours (cell line U87). Lovastatin $2 \mu \mathrm{M}+$ atorvastatin $0.48 \mu \mathrm{M}+$ pioglitazone $10 \mu \mathrm{M}$ reduced the survival to $50.6 \%$ of viable cells, which means respectively a $2.5-$, 3 - and 4-fold lower dose than the maximally tested dose each (Figure 2B).

\section{Reversion of the statins' effect and TDZ}

The co-administration of Geranylgeranyl-Pyrophosphate (GGPP) and Farnesyl Pyrophosphate (FPP) reversed the effect of statins in all experiments (cell survival >90\%). Interestingly, the pioglitazone effect was slightly augmented with GGPP $10 \mu \mathrm{M}$ or FPP $10 \mu \mathrm{M}$, which caused $53 \%$ respectively $64 \%$ surviving cell, after $48 \mathrm{~h}$ in cell line U87. In case of combinations of two statins the GGPP or FPP produced an effect reversion as well as increased growth $(>100 \%)$, but not in combination of statin with TDZ (difference $<2 \%$ ).

The inhibitor of PPAR-y, GW9662, was unable to prevent the cytotoxicity promoted by pioglitazone. The effects of statins as single drug or combination of 2 statins were reverted by $20 \mu \mathrm{M}$ GW9662 with a mean cell survival $>90 \%$. Combinations of statin with pioglitazone were not affected by adding GW9662.

\section{Fluorometric caspase 3 activity after 48 hours on cell line U87}

The maximal increase of caspase 3 activity of $28 \%$ was registered for the combination of atorvastatin 1.5 $\mu \mathrm{M}$ with lovastatin $5 \mu \mathrm{M}(\mathrm{p}<0.001)$. Lovastatin at $5 \mu \mathrm{M}$ alone was unable to induce caspase 3 activity. Pioglitazone $40 \mu \mathrm{M}(13.23 \%, \mathrm{p}=0.15)$ or atorvastatin $1.5 \mu \mathrm{M}+$ PGZ $40 \mu \mathrm{M}(12.73 \%, \mathrm{p}=0.17)$ showed a discrete activation only.

Effects under hypoxia 
Some drugs and their combinations were tested under hypoxic conditions of $0.1 \%$ O2 for 24 hours. Regarding statins the effect of lovastatin was not influenced by hypoxia on U87, but reduced on RG II $(\mathrm{p}=0.002)$. Hypoxia increased the toxicity of atorvastatin on $\mathrm{U} 87(\mathrm{p}=0.01)$ and did not influence the results on RG II. For pioglitazone on the cell line U87 and RG II no different results were obtained under hypoxia. After 24 hours the combination atorvastatin or lovastatin and pioglitazone as well as lovastatin and atorvastatin did not show differences regarding oxygenation conditions in cell lines U87 and RG II.

\section{Discussion}

Despite the best management available, survival of patients with glioblastoma is still very poor until now. This aggressive tumour requires a wide spectrum of therapeutic approaches. Among the molecular mechanisms related to growth of glioblastoma the Ras-MAPK pathway have been proposed as an important target. Prerequisite for Ras activation are isoprenoids, e.g. Geranylgeranyl- und Farnesyl Pyrophosphate [23]. Statins limit their production and therefore Ras and similar molecules (Rho, Rac) are regulated [20]. Multiple molecules related to cell cycle regulation are modulated as consequence [7, 13, 33, 41]. Several studies have described the existence of a considerable cytotoxic effect of statins on glioma cells $[4,6,7,13,15,20,21,24,33,38,41]$. Apoptosis induction was discussed as main cytotoxic mechanism of lovastatin in glioma cells due to its TRAIL-sensitizing effect [7] and due to the stimulation of the expression of the pro-apoptotic protein Bim [20]. The estimated dose required for achieving this cytotoxic effect is so high, that a clinical application is difficult. It is noteworthy that no activation of caspase- 3 with $5 \mu \mathrm{M}$ lovastatin and only limited activation by combined statins were observed in the present study.

Current studies on different kinds of tumours are controversial, because statins could also enhance the growth of cells [17]. This phenomenon could be related to the specific kind of statin, similar to cardiovascular prevention, immunomodulation, and neuroprotection, where intermolecular differences conduce to different pleiotropic effects $[29,40,50]$. With our results, we confirmed this variability of pleiotropic effects of statins as chemotherapeutic agents. We confirmed the efficiency of previously by Yao et al suggested dose of $5 \mu \mathrm{M}$ lovastatin [49]. It is improbable to achieve this dose in clinical trials 
without unwanted side effects. Using Lovastatin in doses ranging from $10 \mathrm{mg} / \mathrm{m}^{2}$ to $415 \mathrm{mg} / \mathrm{m}^{2} \mathrm{Holstein}$ et al could demonstrate a peak plasma bioactivity of $0.06-12.3 \mu \mathrm{M}$. Only two patients, however, reached a concentration $>5 \mu \mathrm{M}[18]$. In the Thibault trial the mean level was $3.9 \mu \mathrm{M}$ [47]. In an animal study Gabryś et al. showed that after administration of lovastatin $50 \mathrm{mg} / \mathrm{Kg}$ a tumour concentration between 0.023 $0.41 \mu \mathrm{M}$ can be obtained. Nevertheless, with this concentration a reduction of the tumour volume was reported [13]. This lower dose could be an explanation for the poor results published in the clinical phase I/II trial with anaplastic astrocytoma and glioblastoma multiforme by Larner et al. [22]. In consideration of pharmacological aspects a similar problem with other statins would be expected. We tested the combination of different statins in order to find a possible synergism related to molecular differences. Rosuvastatin or atorvastatin (synthetic statins) could significantly increase the cytotoxicity, when combined with a natural statin. A dose reduction was possible for the combination with lovastatin (from 5 to $0.5 \mu \mathrm{M}$ ) while the cytotoxic effect remained unchanged. In this way a combination appears feasible to achieve a clinically tolerable concentration of the statins, for example, lovastatin until maximal serum concentration of $0.5 \mu \mathrm{M}$. On primary cultures of cortical astrocytes of rats we found a dose-dependent light toxicity of the assessed drugs. However, the cytotoxic effect of a high dose regimen towards malignant glioma cells was much more pronounced (data not shown).

Recently PPAR- $\gamma$ was described as a target in the treatment of brain tumours [27]. Some studies have been performed on glioma cells. The results were very promising $[3,8,16,28,30,35,36,38,39,42,43,44$, 51]. Our study revealed that the PPAR-Y agonist pioglitazone is more cytotoxic than rosiglitazone. This finding is relevant because pioglitazone is the only TZD that has been shown to significantly pass the blood-brain barrier [28].

Some studies have tried successfully to combine TDZ with other therapies [39, 44]. So far just one study combined lovastatin and troglitazone with a very high synergic effect [49]. A superiority of troglitazone is widely suggested [8, 49]. Its clinical use, however, is quite limited because of its hepatotoxicity, which was the reason for the withdrawal of troglitazone from the market [11]. We tested the combination of different statins with the two currently available TDZ. We found a better potentiating effect with pioglitazone. Using this combination it was possible to reduce the dose rate. $5 \mu \mathrm{M}$ pioglitazone with 
atorvastatin was nearly as effective as $40 \mu \mathrm{M}$ pioglitazone plus atorvastatin. After 48 hours a similar effect of one single statin or statin plus TDZ each at maximal dose can be reached by combining two statins and one TDZ, at significantly reduced dose rates (lovastatin around $2.5 \mu \mathrm{M}$, atorvastatin $1 \mu \mathrm{M}$, and pioglitazone $5 \mu \mathrm{M})$.

As previously suggested, isoprenoids compensate the statin effects [33]. We could confirm this phenomenon after application of isoprenoids GGPP and FPP. As these molecules are required for activation of MAPKs-dependent pathways via activation of GTPases like Ras, Rho, and similar, we can suggest that this pathway of cell proliferation may be one target of statins in neurooncology.

A possible activation of PPAR by statins has been proposed and studies on monocytes showed an activation of MAPK and PPAR- $\gamma$ by statins [1,38]. Accordingly, the PPAR- $\gamma$ inhibitor GW 9662 slightly affects the statin action in our series. Some studies with TDZ suggested that the antitumor effect is not related to PPAR-Y activation $[3,39]$. This suggestion for administration of PPAR-Y inhibitor was only partially confirmed in this study.

The caspase 3 activity was minimally increased by pioglitazone and unaffected by lovastatin alone. The combination of statin and TDZ produced a slight increase of caspase activity, while it was significantly stimulated by a combination of two statins. TDZ is argued to facilitate caspase 8 and 9 and TRAILinduced apoptosis $[3,51]$, however this seems not to be the main mechanism. Inactivation of STAT 3 , down-regulation of FLIP and Bcl-2 are additional mechanisms considered for apoptosis induction of TDZ $[3,39]$. Up to now there is scarce evidence of caspase activation by statin on glioma, even if this possibility has been observed with myeloma cells [5]. Experimental evidence showed the proapoptotic properties of statin on several kinds of tumours $[4,45]$. The possible mechanism for that is an upregulation of proapoptotic proteins like Bax and Bim in combination with downregulation of antiapoptotic proteins (Bcl-2) $[20,26,46]$. In order to fully explain the enhancement of cytotoxicity, especially of the combination of statin with TDZ, other death cell mechanisms need to be assessed because only a weak effect of caspase 3 activation could be detected in this study.

Hypoxia plays a predominant role in tumour development, angiogenesis and growing in many human tumours [19]. The necrotic areas found in glioblastoma look like hypoxic regions, although the 
contribution of hypoxia to this phenomenon is not clear. Hypoxia, however can lead to increased tumour invasion, reduced apoptosis, chemo-resistance, resistance to antiangiogenic therapy and radio-resistance [25]. We therefore assessed the performance of statins and TDZ under hypoxic conditions. Since cell cultures are very critical under hypoxic conditions these experiments were accomplished for $24 \mathrm{~h}$ only. Despite this short incubation time of 24 hours with the medication, a modest cytotoxic effect can be observed. The effect of single therapy with statins alone was reduced while pioglitazone or combinations of statin with TDZ were not influenced. Hence, by an approach combining statins with TDZ it would be possible to limit the tumour resistance generated by hypoxia.

An additional antitumor effect of statins in vivo may be attributed to immunomodulation. An increased IL-18 production can be stimulated by statins; this cytokine regulates natural killers and other lymphocytic cells [46]. On the other hand there is evidence for an immunomodulator role of TDZ, in oncology especially important would be IL-2 [26].

In vivo studies showed a weak effect of statin and TDZ as single therapy. In vivo both substances as single therapy can reduce the tumour volume, even if applied orally $[13,16,44]$. It could be possible that our observed effects won't be achieved in vivo, because of the variability in cell lines and the pharmacological properties of the applied drugs. In vivo studies with the combination of statins and TDZ, however, are still missing. This kind of studies and pharmacologic studies in humans are needed to determine the safety of such a combined therapy.

Of course, we cannot fully explain the mechanism of the cytotoxic effect until now, the different pleiotropic effects of statins and TDZ, however, should be considered as relevant for neuro-oncology. Recently we showed the significant effects of this therapy in meningeoma cells as well [14]. Some antitumor effects of statins alone have been demonstrated in murine models, including nude mice [13] and recently the most appropriate, orthotopic model. The latter exploits syngeneic glioma cells implanted into the brains of normal, immunocompetent mice [52]. In this model, a dual behavior of simvastatin was observed, depending on the dose range, with tumor necrosis and apoptosis being enhanced only for the low dose regimen [52]. The high dose regimen increased the vessel diameters, suggesting adverse effects. Our study strongly supports, that a combination of namely pioglitazone, lovastatin (natural statin), and 
atorvastatin (synthetic statin) had to be tested on an in vivo model, preferentially in the orthotopic mouse glioma model, as a feasible approach for glioma therapy.

\section{Acknowledgements}

We thank Ines Schellhase for her technical assistance in preparation of cell cultures. We thank AstraZeneca for the donation of the salt.

\section{References}

1. Agarwal B, Bhendwal S, Halmos B, Moss SF, Ramey WG, Holt PR (1999) Lovastatin augments apoptosis induced by chemotherapeutic agents in colon cancer cells. Clin Cancer Res 5: 2223.

2. Amarenco P, Bogousslavsky J, Callahan A 3rd, Goldstein LB, Hennerici M, Rudolph AE, et al (2006) Stroke Prevention by Aggressive Reduction in Cholesterol Levels (SPARCL) Investigators. Highdose atorvastatin after stroke or transient ischemic attack. N Engl J Med 355: 549.

3. Akasaki Y, Liu G, Matundan HH, Ng H, Yuan X, Zeng Z, Black KL, Yu JS (2006) A peroxisome proliferator-activated receptor-gamma agonist, troglitazone, facilitates caspase- 8 and -9 activities by increasing the enzymatic activity of protein-tyrosine phosphatase-1B on human glioma cells. J Biol Chem 281: 6165.

4. Bouterfa HL, Sattelmeyer V, Czub S, Vordermark D, Roosen K, Tonn JC (2000) Inhibition of Ras farnesylation by lovastatin leads to downregulation of proliferation and migration in primary cultured human glioblastoma cells. Anticancer Res 20: 2761.

5. Cafforio P, Dammacco F, Gernone A, Silvetris F (2005) Statins activate the mitochondrial pathway of apoptosis in human lymphoblasts and myeloma cells. Carcinogenesis 26: 883.

6. Cemeus C, Zhao TT, Barrett GM, Lorimer IA, Dimitroulakos J (2008) Lovastatin enhances gefitinib activity in glioblastoma cells irrespective of EGFRvIII and PTEN status. J Neurooncol 90: 9.

7. Chan DY, Chen GG, Poon WS, Liu PC (2008) Lovastatin sensitized human glioblastoma cells to TRAIL-induced apoptosis. J Neurooncol 86: 273. 
8. Coras R, Hölsken A, Seufert S, Hauke J, Eyüpoglu IY, Reichel M, et AL (2007) The peroxisome proliferator-activated receptor-gamma agonist troglitazone inhibits transforming growth factor-betamediated glioma cell migration and brain invasion. Mol Cancer Ther 6: 1745.

9. Demetri GD, Fletcher CD, Mueller E, Sarraf P, Naujoks R, Campbell N, Spiegelman BM, Singer S (1999) Induction of solid tumor differentiation by the peroxisome proliferatoractivated receptor- $Y$ ligand troglitazone in patients with liposarcoma. PNAS 96: 3951.

10. Dimitroulakos J, Thai S, Wasfy GH, Hedley DW, Minden MD, Penn LZ (2000) Lovastatin induces a pronounced differentiation response in acute myeloid leukemias. Leuk Lymphoma 40: 167.

11. Dimitroulakos J, Ye LY, Benzaquen M, Moore MJ, Kamel-Reid S, Freedman MH, Yeger H, Penn LZ (2001) Differential sensitivity of various pediatric cancers and squamous cell carcinomas to lovastatin induced apoptosis: therapeutic implications. Clin Cancer Res 7: 158.

12. Fletcher B, Berra K, Ades P, Braun LT, Burke LE, Durstine JL, et al (2005) Managing Abnormal Blood Lipids: A Collaborative Approach. Circulation 112: 3184.

13. Gabryś D, Dörfler A, Yaromina A, Hessel F, Krause M, Oertel R, Baumann M (2008) Effects of lovastatin alone or combined with irradiation on tumor cells in vitro and in vivo. Strahlenther Onkol 184: 48 .

14. Gehring S, Tapia-Pérez JH, Kirches E, Firsching R, Keilhoff G, Schneider T, Mawrin C (in press) Cytotoxic effects of statins and thiazolidinediones on meningioma cells. J Neuro-oncol in press.

15. Gliemroth J, Zulewski H, Arnold H, Terzis AJ (2003) Migration, proliferation, and invasion of human glioma cells following treatment with simvastatin. Neurosurg Rev 26: 117.

16. Grommes C, Landreth GE, Sastre M, Beck M, Feinstein DL, Jacobs AH, Schlegel U, Heneka MT (2006) Inhibition of in vivo glioma growth and invasion by peroxisome proliferator-activated receptor gamma agonist treatment. Mol Pharmacol 70: 1524.

17. Hindler K, Cleeland CS, Rivera E, Collard CD (2006) The role of statins in cancer Therapy. Oncologist 11: 306 .

18. Holstein Sa, Knapp HR, Clamon GH, Murry DJ, Hohl RJ (2006) Pharmacodynamic effects of high dose lovastatin in subjects with advanced malignancies. Cancer Chemother Pharmacol 57: 155. 
19. Jensen R (2009) Brain tumor hypoxia: tumorigenesis, angiogenesis, imaging, pseudoprogression, and as a therapeutic target. J Neurooncol 92: 317.

20. Jiang Z, Zheng X, Lytle RA, Higashikubo R, Rich KM (2004) Lovastatin-induced up-regulation of the BH3-only protein, Bim, and cell death in glioblastoma cells. J Neurochem 89; 168.

21. Jones KD, Couldwell WT, Hinton DR, Su Y, He S, Anker L, Law RE (1994) Lovastatin induces growth inhibition and apoptosis in human malignant glioma cells. Biochem Biophys Res Commun 205: 1681 .

22. Kang DW, Choi CH, Park JY, Kang SK, Kim YK (2008) Ciglitazone induces caspase-independent apoptosis through down-regulation of XIAP and survivin in human glioma cells. Neurochem Res 33: 551.

23. Kanu OO, Mehta A, Di C, Lin N, Bortoff K, Bigner DD, Yan H, Adamson DC (2009) Glioblastoma multiforme: a review of therapeutic targets. Expert Opin Ther Targets 13:701.

24. Koyuturk M, Ersoz M, Altiok N (2004) Simvastatin induces proliferation inhibition and apoptosis in C6 glioma cells via c-jun N-terminal kinase. Neurosci Lett 370: 212.

25. Larner J, Jane J, Laws E, Packer R, Myers C, Shaffrey M (1998) A phase I-II trial of lovastatin for anaplastic astrocytoma and glioblastoma multiforme. Am J Clin Oncol 21: 579.

26. Lichtor T, Glick RP (2003) Cytokine immuno-gene therapy for treatment of brain tumors. J NeuroOncol 65: 247.

27. Lichtor T, Spagnolo A, Glick RP, Feinstein DL (2008) PPAR-Y Thiazolidinedione Agonists and Immunotherapy in the Treatment of Brain Tumors. PPAR Res 2008: 547470.

28. Maeshiba Y, Kiyota Y, Yamashita K, Yoshimura Y, Motohashi M, Tanayama S (1997) Disposition of the new antidiabetic agent pioglitazone in rats, dogs, and monkeys. Arzneimittelforschung 47: 29.

29. Mason RP, Walter MF, Day CA, Jacob RF (2005) Intermolecular Differences of 3-Hydroxy-3Methylglutaryl Coenzyme A Reductase Inhibitors Contribute to Distinct Pharmacologic and Pleiotropic Actions. Am J Cardiol 96 [suppl]: 11F.

30. Masubuchi Y (2006) Metabolic and non metabolic factors determining troglitazone hepatotoxicity: A review. Drug Metab Pharmakokinet 21: 347. 
31. Minniti G, Muni R, Lanzetta G, Marchetti P, Enrici RM (2009) Chemotherapy for glioblastoma: current treatment and future perspectives for cytotoxic and targeted agents. Anticancer Res 29:5171.

32. Nicholas MK (2007) Glioblastoma multiforme: evidence-based approach to therapy. Expert Rev Anticancer Ther 7(12 Suppl):S23.

33. Obara S, Nakata M, Takeshima H, Kuratsu J, Maruyama I, Kitajima I (2002) Inhibition of migration of human glioblastoma cells by cerivastatin in association with focal adhesion kinase (FAK). Cancer Lett 185: 153 .

34. Palakurthi SS, Aktas H, Grubissich LM, Mortensen RM, Halperin JA (2001) Anticancer effects of thiazolidinediones are independent of peroxisome proliferator-activated receptor $Y$ and mediated by inhibition of translation initiation. Cancer Res 61: 6213.

35. Papi A, Tatenhorst L, Terwel D, Hermes M, Kummer MP, Orlandi M, Heneka MT (2009) PPARgamma and RXRgamma ligands act synergistically as potent antineoplastic agents in vitro and in vivo glioma models. Neurochem 109: 1779 .

36. Pérez-Ortiz JM, Tranque P, Burgos M, Vaquero CF, Llopis J (2007) Glitazones induce astroglioma cell death by releasing reactive oxygen species from mitochondria: modulation of cytotoxicity by nitric oxide. Mol Pharmacol 72: 407.

37. Pichlmeier U, Bink A, Schakert G, Stummer W, the ALA Glioma Study Group (2008) Resection and survival in glioblastoma multiforme: An RTOG recursive partitioning analysis of ALA study patients. Neuro-Oncol 10: 1025.

38. Prasanna P, Thibault A, Liu L, Samid D (1996) Lipid metabolism as a target for brain cancer therapy: synergistic activity of lovastatin and sodium phenylacetate against human glioma cells. J Neurochem 66: 710.

39. Schultze K, Böck B, Eckert A, Oevermann L, Ramacher D, Wiestler O, Roth W (2006) Troglitazone sensitizes tumor cells to TRAIL-induced apoptosis via down-regulation of FLIP and Survivin. Apoptosis 11: 1503. 
40. Sironi L, Gianazza E, Gelosa P, Guerrini U, Nobili E, Gianella A, Cremonesi B, Paoletti R, Tremoli E (2005) Rosuvastatin, but not simvastatin, provides end-organ protection in stroke-prone rats by antiinflammatory effects. Arterioscler. Thromb Vasc Biol 25: 598.

41. Soma MR, Baetta R, Bergamaschi S, De Renzis MR, Davegna C, Battaini F, Fumagalli R, Govoni S (1994) PKC activity in rat C6 glioma cells: changes associated with cell cycle and simvastatin treatment. Biochem Biophys Res Commun 200: 1143.

42. Soma MR, Baetta R, De Renzis MR, azzini G, Davegna C, Magrassi L, Butti G, Pezzotta S, Paoletti R, Fumagalli R (1995) In vivo enhanced antitumor activity of carmustine [N,N'-bis(2-chloroethyl)-Nnitrosourea] by simvastatin. Cancer Res 55: 597.

43. Soma MR, Pagliarini P, Butti G, Paoletti R, Paoletti P, Fumagalli R (1992) Simvastatin, an inhibitor of cholesterol biosynthesis, shows a synergistic effect with N,N'-bis(2-chloroethyl)-N-nitrosourea and beta-interferon on human glioma cells. Cancer Res 52: 4348.

44. Spagnolo A, Glick RP, Lin H, Cohen EP, Feinstein DL, Lichtor T (2007) Prolonged survival of mice with established intracerebral glioma receiving combined treatment with peroxisome proliferatoractivated receptor-gamma thiazolidinedione agonists and interleukin-2-secreting syngeneic/allogeneic fibroblasts. J Neurosurg 106: 299.

45. Spagnolo A, Grant EN, Glick R, Lichtor T, Feinstein DL (2007) Differential effects of PPARgamma agonists on the metabolic properties of gliomas and astrocytes. Neurosci Lett 417: 72.

46. Takahashi HK, Weitz-Schmidt G, Iwagaki H, Yoshino T, Tanaka N, Nishibori M (2006) Hypothesis: the antitumor activities of statins may be mediated by IL-18. J. Leukoc Biol 80: 215.

47. Thibault A, Samid D, Tompkins AC, Figg WD, Cooper MR, Hohl RJ, Trepel J, Liang B, Patronas N, Venzon DJ, Reed E, Myers CE (1996) Phase I study of lovastatin, an inhibitor of the mevalonate pathway, in patients with cancer. Clin Cancer Res 2:483.

48. Yano M, Matsumura T, Senokuchi T, Ishii N, Murata Y, Taketa K, et al (2007) Statins activate peroxisome proliferator-activated receptor gamma through extracellular signal-regulated kinase $1 / 2$ and p38 mitogen-activated protein kinase-dependent cyclooxygenase- 2 expression in macrophages. Circ Res 100: 1442. 
49. Yao CJ, Lai GM, Chan CF, Cheng AL, Yang YY, Chuang SE (2006) Dramatic synergistic anticancer effect of clinically achievable doses of lovastatin and troglitazone. Int J Cancer 118: 773.

50. Zacco A, Togo J, Spence K, Ellis A, Lloyd D, Furlong S, Piser T (2003) 3-Hydroxy-3-Methyilglutaryl Coenzime A Reductse Inhibitors protect cortical Neurons from excitotoxicity. J Neurosci 23: 1104.

51. Zander T, Kraus JA, Grommes C, Schlegel U, Feinstein D, Klockgether T, et al (2002) Induction of apoptosis in human and rat glioma by agonists of the nuclear receptor PPARgamma. J Neurochem 81: 1052.

52. Bababeygy SR, Polevaya NV, Youssef S, Sun A, Xiong A, Prugpichailers T, Veeravagu A, Hou LC, Steinman L, Tse V (2009) HMG-CoA reductase inhibition causes increased necrosis and apoptosis in an in vivo mouse glioblastoma multiforme model. Anticancer Res 29:4901. 
Figure 1. Effects of TDZ and statins against U87 and U 138 (human) glioblastoma cells in vitro. Cells were seeded in 96-well plates (2,000 cells/well) for $24 \mathrm{hr}$ and then treated with the indicated concentrations for 48 and 144 hours. Cell numbers are expressed as a relative viability (\% of control), mean \pm standard deviation. $\mathrm{ATVS}=$ atrovastatin, $\mathrm{LVS}=$ lovastatin, $\mathrm{PGZ}=$ pioglitazone, $\mathrm{PVS}=$ pravastatin, $\mathrm{RGZ}=$ rosiglitazone, $\mathrm{RVS}=$ rosuvastatin, $\mathrm{SMV}=$ simvastatin.

Figure 2. Synergistic effects on U87 human glioblastoma cells of: A) Atorvastatin with increasing dose and constant lower dose $(5 \mu \mathrm{M})$ of pioglitazone and B) Three substances: atorvastatin + lovastatin + pioglitazone. Cells were treated with the indicated concentrations for $48 \mathrm{~h}$. Cell numbers are expressed as a relative viability (\% of control), mean \pm standard deviation. $A T V S=$ atorvastatin, $L V S=$ lovastatin, $\mathrm{PGZ}=$ pioglitazone. 